\title{
On the Commons: A Geocritical Reading of Amager Falled
}

\author{
Elisabeth Friis
}

This chapter proposes a geocritical reading of a rather inconspicuous place in Denmark, which nonetheless stands out by virtue of its strikingly insistent appearance in Danish literature during the past three years. To read geocritically means, in Bertrand Westphal's phrasing, to examine "the multifocalization of viewpoints on a given reference space"l (Westphal 2007,188 ), and this is precisely what the place that I shall be examining makes possible, since quite a lot has actually been written about it recently. In order to practice Westphal's geocentric criticism (as opposed to what happens in what he calls geocentric or imagological criticism), it is moreover of decisive importance to take the referentiality of an actual place as a starting point: "geocritics confront a referent whose literary representation is no longer considered a deformation, but a foundation" (Westphal 2007, 186).

This means two things. First, that we take the geographical determination of specific places seriously. And second, that we don't consider literary representations as independent of this place or completely different from the specific location they represent.

E. Friis $(\bowtie)$

Lund University, Lund, Sweden

(C) The Author(s) 2020

K. Malmio, K. Kurikka (eds.), Contemporary Nordic Literature

and Spatiality, Geocriticism and Spatial Literary Studies,

https://doi.org/10.1007/978-3-030-23353-2_2 
Place as "a given reference space" and place as "literary representation" are thus not mutually exclusive categories - far from it. The traffic between those perspectives is dense, and getting a grip on it is exactly what Westphal's geocritical method allows us to do.

Following Westphal, I shall regard the specific place that is of interest here, Amager Falled (or in English, Amager Common) as a place whose specificity engenders specific movements within the literature that interacts with it. Westphal's theoretical basis is one that is both eclectic and interdisciplinary, but Gilles Deleuze and Félix Guattari's philosophy of spatial formations - territorialization, deterritorialization, reterritorialization, the parceling out of striated space, and the nomadic distribution of smooth space-is a constant point of reference, just as it is going to be an important point for the present analysis in combination, on and off, with the political-theoretical discussion of both the historical and present import of the commons in the era of (late) capitalist modernity.

It may also be noted that my reason for pointing to Westphal (and not just to Deleuze and Guattari) as a central reference here is a methodological one. Westphal connects virtual space with actual space in a way that is not really practiced by Deleuze and Guattari. Where, for example, does the (literary) line of flight begin? In what specific reference is it fixed? $A$ Thousand Plateaus has no general answer to that, but I understand Westphal's geocriticism as a response to that very question: He engages in a distinct reflection upon how to approach the specificity of sites.

\section{Amager: And Amager Common}

Next to Copenhagen is Amager, an island of $96.29 \mathrm{~km}^{2}$ connected to the center of the capital of Denmark by two bridges. To an outside observer, Copenhagen and Amager are by and large one and the same place-it takes five minutes to cross the bridges by foot, and no time at all on a bicycle. But it is not just water and bridges that separate Copenhagen from Amager. You move "out" into Amager and "into" the city- the "city" can never be Amager. Seen from Copenhagen, Amager has almost always been viewed as either a wasteland or a low-status area.

The famous Danish writer and actress Johanne Luise Heiberg's (1812-1890) description of Amager ${ }^{2}$ in her memoirs Et Liv gjenoplevet $i$ Erindringen ("A Life Recalled in Memory"), posthumously published in 1891-1892, is thus both symptomatic and atypical of the relationship of Copenhageners to the island-then and now: 
This poor, flat island, little noticed by Copenhageners, I had granted my particular favours. Here, one had not the pleasure of seeing a single dressed up Copenhageners; one was met only by Amager's peasant life. (...) I do believe that no one in the entire city of Copenhagen knows the beauty of Amager as I do; perhaps I have a peculiar taste for exactly this kind of beauty, the beauty of the plains, where the eye meets no obstacle, but reaches forward indefinitely, only to be stopped by the arch of heaven. (...)

My friends often laughed at my love for this flat, and as they dared say, foul Amager. (Heiberg 1944, 192)

And "foul" Amager has not on the whole been made more attractive to "Copenhageners" by the past 150 years' urban development. In Morten Pape's autobiographical debut Planen (2015; "The Plan"), depicting the author's upbringing in the largest social housing project in the island, Urbanplanen, Amager is described in the following terms:

Many years ago the capital's shit and waste were stored in these parts. The shitty island of Amager was the place to hide the ugliness. Today its waste dump symbolism cannot be overlooked. Now this is the place you don't want your children to go near. Pale potatoes like myself are outnumbered. There are more headscarves than tulle skirts, and more Arabic is sung in the corners than Halfdan Rasmussen at the hopscotch grid. The grown-ups say it is because our school lies in the middle of a ghetto. (Pape 2015,4)

A popular name for Amager is "Shitty Island," with reference to the fact that a cleaning station for Copenhagen's latrines was long located there. From 1777 onward, the open, so-called chocolate wagons drove overfilled soil tubs out from the city to the great soil pit on Amager (Lindegaard 2001). And as far as the "waste dump symbolism" is concerned, great amounts of waste have continuously been deposited on the island-in many cases toxic waste, for instance from ØK's (Det Østasiatiske Kompagni or the East Asiatic Company, EAC) infamous soy bean cake factory. ${ }^{3}$ In an even darker vein, from 1806 Amager hosted Copenhagen's execution site, just as it was the home of the "Slave Graveyard" (abolished 1857), where prisoners convicted to hard labor (known in those days as "slaves") found their last resting place; they were buried in layers-and needless to say, in the cheapest of coffins.

But Amager also, as we learn from Mrs. Heiberg's praise of the island's nature, of its "beauty of the plains," has been an ambiguous place, since "foul" Amager supplied Copenhagen with vegetables for centuries. 
Whether these products were fertilized using excrement from the latrine pit is hard to tell, but the market gardeners have a history of their own, being Dutch immigrants who as early as the 1500s were invited to settle in Amager by Denmark's king, Christian II, supplying the country's capital with vegetables into the twentieth century, and gaining Amager not only the epithet of Shitty Island but also the title of "The Larder of Copenhagen."

If the status of historical Amager is certainly complex, its complexity has not diminished today.

On Amager lies Københavns Universitet Amager (KUA) - , the Faculty of Humanities of the University of Copenhagen-soon to be Campus South, with Law and Theology joining in. On Amager lies Copenhagen Airport - the largest airport in Scandinavia. On Amager lies Denmark's biggest shopping mall, Fields, built as a direct outcome of the very expensive construction of a new metro, in connection with urban development modeled on London's Docklands. And right in the midst of Amager we find our primary object of study: Amager Falled or Amager Common-a natural area consisting partly of land that has been claimed from the sea and partly of a salt marsh whose flora and fauna has remained largely undisturbed for 5000 years.

Here grow rare plants like Filipendula vulgaris and Selinum dubium, and here one stands a chance of seeing the red-listed hoverfly Xanthogramma festivum and many other insects that do not thrive on cultivated land. Overall, the soil of Amager Common is poor, which is why it has been used for pasture, and later as a military terrain. Since the military abandoned its positions, the Common has been open to the public and put to multiple uses. People gather berries and herbs in the area. Romani trailers have come and gone. Nowadays, stranded refugees-and indeed the homeless of the world-sleep under tarpaulins. Asa worshippers gather and perform blót. ${ }^{4}$ And gay people have sex in the bushes. There are "shelters" put up by authorities so that anybody can sleep out there for a night or two, and safely light their campfire. There is a shop for renting bicycles, students getting some fresh air-all of these activities accompanied by a tight chain of airplanes cutting through the air above people's heads, and above the livestock that still grazes here and there.

Without the least exaggeration, all sorts of biodiversity can be said to blossom on Amager Falled, so that this felled forms a distinct form of geographical space.

It is time to make a couple of space-theoretical categorizations. 


\section{WHAT Is A FÆLLED?}

Falled originally designates an area where all the livestock (in Danish, $f_{\mathfrak{e}}$ ) are put to pasture. It is a common space (in Danish, falled means "common"), a space of the community (the Danish word for "community" is fellesskab), meaning that the notion of both livestock and community or commonness is semantically implied by the word felled. In Marx's (1867) classical analysis, the enclosure of the commons-the fencing-in of fields formerly used for grazing and cultivation in common ${ }^{5}$ - heralds the advent of the type of control over production that forms the basis of original accumulation on which modern capitalism is founded. ${ }^{6}$

The debate over the historical significance of common (nonterritorialized) areas is flourishing on a global level. For obvious reasons, the question of "enclosure" versus the maintenance of some kind of commons is pressing in many "less developed" regions-whereas in "overdeveloped" areas environmentalists are trying to stake a claim for alternative principles of common cultivation which would be both sustainable and community-strengthening (urban gardening is perhaps the most wellknown example of this). How to conceptualize our "common ground" and how to put it to good use are of course burning questions of great environmental importance, as well as being equally important in connection with the problem of the distribution of income and wealth. To capitalize land that is actually the home of people who live on it ranks, for instance, among the specialties of the World Bank, ${ }^{7}$ whose modus operandi raises the question of what may, in the broadest sense, be considered to be "common": water, air, plants, that which sustains us on the planet we inhabit together with approximately 8.7 million other living species, whose right to exist, as is well known, is not counted among the top priorities of human societies.

The curve of biodiversity both locally and globally moves downward. In overdeveloped Denmark (55.8\% of the country's surface is cultivated, making Denmark the world's most intensely farmed nation), the Xanthogramma festivum on Amager Falled is not the only species fighting for its life. As these lines are written, 2262 species of plants and animals are on the so-called red list-an inventory following the guidelines of the International Union for Conservation of Nature (IUCN), which covers the species that are threatened in Denmark.

But a specific area's degree of biodiversity is not only related to the diversity of its species (including its microbiological diversity). 
Amager Common is by no means a pristine natural reserve- the area is constantly put to use, for anything from picking elderflowers to having anonymous sex. Being on the common, a shopping mall and the metro line are close at hand-as planes go over your head-the common indeed is a place in use, and if we think of it as an "environment," 8 it is an environment that includes Kentucky Fried Chicken and whatever has lately rolled off the assembly line at Boeing.

At the same time this is a nomadic space-both in the tangible sense of its housing Romani trailers and homeless asylum seekers, and in Deleuze and Guattari's sense, that is to say it is a space which is not determined through parceling (an infrastructure based upon private property-the space as an espace strié/striated space), but is rather drawn up through the movements of the bodies that are in motion across it (the space as an espace lisse/smooth space).

We could simply say that the space becomes a space as a consequence of these movements - and it is my claim that this is exactly what also happens in the treatment of Amager Felled in contemporary Danish literature. As Westphal puts it, "at the interface between world and text, events produce themselves that are otherwise complex and ambitious (for literature) than the mere rendering [la pure presentation] of a service" (Westphal 2007, 185), and as we shall see The Common is quite simply a space that stimulates a certain type of literary distribution.

Furthermore, the idea of The Common as a place that has not yet been capitalized, that is, a place in which capitalist exploitation is not (yet) active-in short a more straightforward Marxist interpretation of the meaning of this place-is also traceable. The poet Liv Sejrbo Lidegaard (born 1986), who published her first book Falleden ("The Common") in 2015, at any rate has the following to say about the significance of Amager Common in an interview with the newspaper Information ("Slaget om Falleden," "The Battle of the Common," October 8, 2016):

The Common has the ability not to be put to much use. Especially when you live in a city, every place has great economic value. And if economic value governs, it can become impossible to be there. This is the opposite. There is no economic value-or there is, and this is why it may not survive. But it hasn't been put to use. The fact that it hasn't been put to much use actually does that you are able to be here. (Villesen 2016) 
When Lidegaard states that Amager Falled is not "put to much use," she is clearly aiming at the area's lack of territorialization by capital, meaning, as she says, "that you are able to be there." We shall return to Lidegaard's perspective and its poetic articulation in Felleden, but first we shall encounter another young Danish poet, Asta Olivia Nordenhof (born 1988), whose poem about, among other things, Amager Common, from her volume of poetry, det nemme og det ensomme (2013; "the easiness and the loneliness"), has become an instant classic in Danish literature. ${ }^{9}$

\section{Asta Olivia Nordenhof: The Tenderness of THE COMMON}

The titleless poem which takes place on The Common is the first long poem in the collection, and it begins with a hangover and the anxiety of death, after which the lyrical I and her partner go for a walk on Amager Felled:

varmen og tømmermændene

jeg fjerner mig fra dem jeg elsker med hele kroppens underlige styrke

fik indsigt i hvordan jeg vil dø

jeg så eksplosionen indefra. fra blodets perspektiv.

jeg var oprørt over det. min kæreste sagde: rolig olli

nu ved jeg det ikke længere, om jeg fik mulighed for at opleve min død som den i paralleltid

allerede er indtruffet

det er ikke sikkert. så senere: vi plukkede vilde blommer og mirabeller på ydre amar

ved solnedgang og metroen drev med sit lys, som et strengt, som et under-

ligt vredt samfund

frem og tilbage på himlen

ingen i fields ingen på kentucky fried chicken

to mennesker foran et parcelhus. sad med txpper på, talte med hinanden

"jeg er meget træt nu" "jeg er også meget træt"

hvorfor er knoglerne ik mere skøre

røde røde sol

du så dejlig du så ligeglad om jeg kaster en blomme i dit navn

og amar hvor ømt du at du gav mig en blomme at kaste

må skrive til morten!

må skrive til bjørn! jorden er øm og jeg er ik nok til at fat det! 
hvordan kan vi blive mer forgæeves, mer beskidte

mer forgæves, prøv at høre ordet:

tak

hvordan! (...) (Nordenhof 2013, 8-9)

heat and hangover

i distance myself from those i love with the strange strength of my whole body

got insight into how i will die

i saw the explosion from inside. from my bloods perspective.

i was upset about it. my boyfriend said "easy, olli"

now i don't know anymore if $i$ got to experience my own death as it already happened, in parallel time

its not certain. then later: we picked wild plums and mirabelles way out in amager

at sunset and the metro swept with its lights, like a severe, like a strangely irascible society

back and forth across the sky

no one in fields no one in the $\mathrm{kfc}$

two people in front of a tract house. sat wrapped in blankets and talked with each other

"im very tired now" "im very tired too"

why arent my bones more brittle

red red sun

you so lovely you so indifferent to whether i throw a plum in your name and amager how tender that you gave me a plum to throw must write to morten!

must write to bjørn! the earth is tender and im not enough to grasp it! how can we be any more pointless, any more dirty

more pointless, listen to the word:

thanks

how! $(\ldots)^{10}$

The first thing to notice is the poem's highlighting of the distinctive geography of Amager Falled. Yes, you can indeed pick wild plums and mirabelles in the Common. And yes, a metro line does in fact cut through the landscape. Fields is the name of the large shopping mall that opened as a result of the development of Ørestaden. ${ }^{11}$ The name Fields itself refers phonetically to the toponomy Falleden (although the precise English translation would have been "The Common"), and Kentucky Fried Chicken is located inside Fields - right next to Ørestad Metro Station. 
Furthermore, Fields borders upon the detached houses of the suburban borough of Tårnby. In other words, the lyrical subject and her partner find themselves in a very real, albeit rather deserted place (it is Sunday), and in this utterly mundane but also stimulating location anxiety about death is replaced by an experience of interconnectedness and solidarity with the surroundings and all that is in them. Opposite to the sunset's democratic coloring of everything in red stands "the metro" ("metroen"), which "swept with its lights, like a severe, like a strangely irascible society/back and forth across the sky" ("drev med sit lys, som et strengt, som et underligt vredt samfund/frem og tilbage på himlen”). In a contemporary Danish context it is hard to find a clearer image of capitalism's territorializing movement-using the "public sector" ("society") as a legitimizing engine $^{12}$ - than the building of the Copenhagen Metro, and the development of Ørestaden that is connected to it. Project "Ørestad" and the construction of the metro were launched by the City of Copenhagen in 1992 in view of capitalizing the unused-but potentially profitable-areas of Amager. The "severe" and "irascible" society's desire for profit is vectorized in the poem by the train that shoots through the Common, but the presence of this movement does not prevent the poem's Amager Folled from being experienced as a very generous place.

Nordenhof's poetry, as is clear from the quoted verse, is marked by the forms of spoken language. Words are spelled as they are pronounced, and as yet another characteristic trait of her texts, all words are in lower-case letters, likewise indicating spoken language-the English translation also marks this by its elimination of the apostrophes. At the same time, the poems are marked by classic devices of "high poetry": metaphor, personification, here in combination with apostrophe, as the Sun and Amager are both personified and apostrophized in the lines "red red sun/you so lovely you so indifferent to whether i throw a plum in your name/and amar [Amager] how tender that you gave me a plum to throw" ("røde røde sol/du så dejlig du så ligeglad om jeg kaster en blomme i dit navn/og amar hvor ømt at du gav mig en blomme at kaste").

As Jonathan Culler remarks in his seminal text on apostrophe, this trope is able to call forth a special form of temporal experience: "The 'now' of the apostrophe is not a moment in a temporal sequence, but a now of discourse - an immediacy. If it works it produces a fictive, discursive event" (Culler 1981, 152). And I wonder whether the apostrophe's independence of sequentiality - the fact that the trope triggers an eventdoes not give rather a precise expression to a certain kind of spatialization: 
The lyrical I throws a plum. It lands wherever it lands, which is a distributive movement that is in clear contrast to the train's "back and forth." This "throwing of a plum in the name of the sun" creates a now within discourse, which is of course able to create, for a moment, a space in the real Amager Falled, but which within the text's poetic, apostrophic discourse also turns into an intense now of perpetual becoming, enhancing the strong sentiment of interconnectedness with the environment which is addressed by the poem. The Sun is "lovely" ("dejlig") because it is "indifferent" ("ligeglad"), a proposition that can be understood in line with an ontological fact: the sun is the only phenomenon known to us that only gives and never takes.

In any case, "amar" is "tender" ("ømt") because it allows us to pick its fruits for free-just like the indifferent sun does. The sun's indifference is no resigned conclusion. It is society, and the will of society, as personified by the metro, that is "severe" and "irascible" (as from the Old Testament)— it is not the sun or the ripe plums on the Common.

Interestingly, nor are Fields and Kentucky Fried Chicken negative places because they are soulless (there is "nobody" inside). The empty consumption spaces seem just as much a part of the surroundings as the plums do. There does not seem to be any difference between the environment that is "natural" and the environment that is "unnatural," the environment that is "manmade" and the environment that is not "manmade" within the space brought forth by the poem, something which is a strong and dark ecological point. ${ }^{13}$

To become more "pointless," more "dirty," would be the wish that we become less obsessed with teleology—we might say with utilitarian thought - and less unmixed with the earth (more dirty), a wish that the poem's gesture of throwing the free plum of amar in the name of the sun will locally realize. The two people sitting outside their tract house are in fact seated outside their house-and thus included in the poem's tenderness toward the place. And without taking the argument too far, one might say that precisely the tract house, at least in a Danish context, is an emblematic figure of the bliss of private property; and how are the two people doing who are sitting under their blankets, looking at the commons? They are tired. 


\section{Lea Løppenthin: The Nomadic Common}

Connecting Amager Falled to Deleuze and Guattari's concept of territorialization/deterritorialization is an idea that is close at hand-not least since Lea Løppenthin's (born 1987) volume of poetry, nervernes adresse (2014, "the address of the nerves") contains a suite of poems which is simply called digt om territorier (poem about territories) - and in this poem we once more find ourselves in Amager Falled:

en nat var vi en gruppe der tog ud på fælleden

vi ville bosætte os afsides i sommeren

hjortene og asylansøgerne er de fastboende i området

vores tøj var mættet af bålets lugt

vi havde siddet ved det i mange timer og bagt vores mad hen over ilden

vi cyklede langs havet, forbi hestene

gennem skoven og over metalbroen, nu skulle vi sove

alle shelters var optagede

alle shelters var bookede af mere forudseende sommergæster

så sov vi i fuglekiggertårnet ved Hejresøen

sov inde i vores soveposer i en Tetris-formation på gulvet

situationen minder om en vinterdag i en lejlighed, jeg boede $\mathrm{i}$

jeg så ned på fortovet, der var dækket af sne

et barn i flyverdragt bar langsomt skovlfulde af sne fra en del af fortovet til en anden

sneen blev fordelt i et mønster rundtomkring på fortovet

den var forsat i vejen for fodgængerne

det kunne jeg rigtig godt lide, ikke det mislykkede ved det (at vi ikke var forudseende på fælleden, at der ikke blev ryddet sne)

det var ikke det mislykkede ved det der var godt

det mislykkede ved det var højst en charme

det var formationerne der optog mig

det mønster vi lå i i tårnet og sneen på fortovet

et mønster vil bruge os, ligesom det fremmede barn jeg så, ville bruge sneen og det lykkedes

det var en succes (...) (Løppenthin 2014, 20)

one night we were a group that went out to the common

we wanted to settle in a remote place in summer

the deer and the asylum seekers are residents there 
our clothes were saturated with the smell of the campfire

we had been sitting by it for many hours baking our food across the fire we rode our bikes alongside the ocean, past the horses

through the woods and over the metal bridge, now we were going to sleep all shelters were taken

all shelters had been booked by better prepared summer guests

so we slept in the bird watching tower next to Heron Lake

we slept in our sleeping bags in a Tetris formation on the floor

the situation recalls a winter's day in an apartment I was living in

i looked down at the sidewalk, which was covered with snow

a child in a siren suit was slowly carrying shovelfuls of snow from one part

of the sidewalk to another

the snow was distributed in a pattern across the sidewalk

it was still in the way for pedestrians

that I really liked, not the failure in it

(that we weren't prepared at the common, that the snow wasn't cleared)

it wasn't the failure in it that was nice

the failure in it was a charm at best

it was the formations that occupied me

the pattern we were lying in in the tower and the snow on the sidewalk that pattern wanted to use us, like the strange child I saw wanted to use the snow

and it happened

it was a success $(\ldots) .{ }^{14}$

The actual surroundings at Amager Falled (campfire, deer, refugees, Heron Lake/"Hejresøen", bird watching tower/"fuglekiggertårnet") become a catalyst for reflections upon how bodies (the group in their sleeping bags, the child in the snow) follow the invisible, that is to say the virtual patterns in space, which is quite another type of pattern-forming movement, or distribution, than the one that takes place in what Édouard Glissant in his Poetics of Relation has so strikingly called arrow-like territorialization. ${ }^{15}$ Let us dwell first on the nomadic implications of the Tetris formation that the sleeping bags form in the bird watchers tower.

Deleuze speaks of nomadic distribution in the tenth series of the Logique $d u$ sens, called "Du jeu idéal"-On the Ideal Game. The game refers to Carroll's Alice in Wonderland which, as is well known, is a constant reference throughout the Logique $d u$ sens-and more specifically to the so-called Caucus-race which Alice attends, mystified. The Caucus-race 
is a running contest in which there are no precise rules for the race's beginning or end, which is why the game has neither winners nor losers. In ordinary games, pre-existing, categorical rules and distributive hypotheses are given in advance (probabilities can be calculated for the throwing of dice, for instance, if the game is continued for a certain while). Ordinary games (Ludo is an obvious example) follow a fixed and distinct numerical distribution-one walks the number of fields that are shown by the eyes of the dice, only to win or lose.

This game, says Deleuze, is a caricature of work and morality (Deleuze $2004,84-5$ ). World economy is governed by the logics of cause and effect, and thinks in terms of means and ends. On the contrary, the results of the Caucus-race are mobile-and they take place in an open space in which the logic of winners and losers is suspended and hypotheses about the outcome are impossible to make. The Caucus-race, then, to Deleuze, is the perfect image of nomadic distribution. And in Løppenthin's text, it is precisely the nomadic distribution of the game or the playing that brings about the experience which the text calls a "success." The sleeping bags "all by themselves" ("af sig selv") make a Tetris formation-that is, a formation which, like the aggregation of forms in the game Tetris, is unpredictable, and the child shuffles snow simply in order to make a pattern; it is being stressed that the action has no utilitarian value- the snow still "got in the pedestrians' way" ("var fortsat i vejen for fodgængerne").

Løppenthin's text also anchors its nomadic theme in the palpable environment of Amager Falled. The group goes into the Common in order "to settle in a remote place in summer" ("at bosætte sig afsides $i$ sommeren"), where the sedentary residents ("de fastboende") are asylum seekers or deer. There are "shelters," but they are occupied by the "summer guests of more foresight" ("better prepared summer guests").

The text deconstructs the difference between "sedentary residents" and "summer guests"-placing its own point of enunciation (the group spending the night in the bird watchers tower) at the center of the deconstructed difference. The equation looks more or less like this: deer and asylum seekers are obviously anything but "sedentary" - the animal has its territory but its boundaries are variable, and asylum seekers are the marginalized of this world; affirmative "nomadism" presupposes open boundaries, which is why one should not believe that the proponents of subjective nomadism are naively paying tribute to the marginalization of the migrant or indulging in some kind of privileged cosmopolitanism. ${ }^{16}$ 
To be true, the "sedentary" of the text are the opposite of just that, and the "shelters" of which it speaks certainly have not been built in order to house asylum seekers, but in order to give the city's residents an opportunity to spend a night surrounded by nature. The group that wants to "settle" in a temporary situation (i.e. "the summer") has not secured a "shelter" for themselves-in order to obtain such shelter it would be necessary to have foresight - and so the distinction between the sedentary and the non-sedentary dissolves as the text slides toward the non-identical. The group places itself in a place-between-the intermezzo of the bird watchers tower-something that corresponds to what Deleuze and Guattari have to say about the nomad:

The nomad has a territory. He follows customary trajectories, he goes from one point to another, he does not ignore the points (water point, dwelling point, assembly point). But the question is what is principle or merely consequence in nomad life. In the first place even though the points determine the trajectories they are strictly subordinate to the trajectories they determine, conversely from what happens with the sedentary. (...) The life of the nomad is intermezzo. (Deleuze and Guattari 1980, 471-2)

The nomadic distribution is thus not the movement of parceling out or of capitalization-it does not parcel out Amager Felled into entities from which someone or something might capitalize or profit-for instance by creating infrastructures (like a metro) to connect two parcels:

The nomad trajectory may well follow customary paths or ways, it does not have the function of sedentary route which is to distribute a closed space to humans, assigning to each one his part, and regulating the communication of these parts. The nomad trajectory does the contrary, it distributes humans (or animals) in a space which is open, indefinite, non-communication. (Deleuze and Guattari 1980, 471-2)

The experiences depicted in both Nordenhof's and Løppenthin's poetry are inseparably intertwined with the specific geography of Amager Falled ("A pattern wanted to use us," "Et mønster ville bruge os"; see Løppenthin). The experiences triggered by precisely this place are experiences of freedom from "the distribution of closed spaces," that is, what we used to call private property. Private property, whose antithesis is the notion of an intrinsically common place: the commons. 
An interesting historical trait of the commons, according to Silvia Federici, is the multiplicity of activities for which these grounds were used in late medieval Europe. The commons not only served as pasture, but also as rallying grounds and meeting places in which to celebrate festive occasions. ${ }^{17}$ As already mentioned, Amager Falled offers Asa believers a place in which to celebrate their rituals, ${ }^{18}$ just as it is a well-known cruising area. ${ }^{19}$

In US LGBTQ (lesbian, gay, bisexual, transgender, queer/questioning) contexts, quite a lot has been written on cruising as well as on the consequences of gentrification for cruising possibilities. To my knowledge, this perspective does not come in a Danish/Scandinavian variety. First, we in Scandinavia lack representations of the implications of cruising space for (especially) homosexuals, and second we have been slow to acknowledge what the desertification that is prompted by gentrification means to our existence. ${ }^{20}$

Then, in 2016, Niels Henning Falk Jensby published his love story $T E C H N O$, in which a central episode depicts a gangbang set in a famous cruising area in Amager Folled.

\section{Niels Henning Falk Jensby: The Sexual Politics OF THE COMMON}

TECHNO's protagonist and his partner have gone on a trip to Amager Folled. Theirs is a very loving relationship, their sexual life marked by the boyfriend's dominant role:

Vi går på brede grusstier på Fælleden, er omkransede af den. Omkring den de nye reservater. Alle de nye bygninger. Glasfacaderne, der spejler det hele kaster sol over det hele. (...) Bunkerne gør det hele uigennemskueligt. Man kan nemt fare vild her, hvis man går væk fra de brede grusstier. Det siger du til mig. Du går hele tiden en halv meter foran mig, har en mærkelig bestemthed i dine skridt. Jeg tror godt jeg ved hvorfor, men jeg påtaler det ikke. (Falk Jensby 2016, 42)

We walk on broad gravel paths in the Common, surrounded by it. All around it is the new reservations. All the new buildings. The facades of glass mirroring everything cast sun over everything. (...) The bushes make it all opaque. It's easy to get lost here if you leave the broad gravel paths. That's what you tell me. All the time you are walking half a yard ahead of me, a strange determination to your steps. I think I know why, but I'm not addressing it. ${ }^{21}$ 
What the protagonist has guessed is that he is to be put at the disposal of other men in the cruising scrubs of the Common-we shall return to this-but what should also be noticed are the terms in which Amager Falled is described. The commons are surrounded by "new reservations" ("nye reservater"), meaning the new neighborhood called Ørestad, which is also Nordenhof's point of departure.

Labeling Ørestaden a "reserve" may imply that Ørestaden can be viewed as a place that is "protected from damaging external influences, and wherein an activity may be carried through without any hindrances or disturbances" (cf. the general definition of the word "reserve"). But calling a neighborhood a "reserve" carries no positive connotation. Here a specific kind of people live (those with means or those without any means), and whereas a natural reserve is created for the protection of biodiversity, the neighborhood-as-reserve constitutes a homogeneous and uniform environment-so the texts proceed to describe it as a world of reflections (the glass facades mirroring everything, throwing sunlight onto everything): in the reserve one "looks into the mirror and thinks it is a window," as Sarah Schulman so poignantly puts it (Schulman 2013, 28).

But in TECHNO the couple is moving away from the glass facades, into the confusion, impossible to survey, of scrubs and thickets:

Du tager min hånd, fører mig med ned ad stien. Buskadset har groet sig ind i plænerne i en sådan formation, at hele denne gruppering ligger skjult for de mennesker, der går ude på de brede grusstier. Det er derfor, brødre kan gå frit herinde, agre frit herinde. Det er derfor de ligger nøgne på txpper på tomme pladser og venter på hinanden herinde. (Falk Jensby 2016, 42)

You take my hand, leading me down the path. The shrubbery has grown its way into the lawns in such a formation that this entire grouping lies hidden from the people walking the broad gravel paths. This is why brothers can move freely here, act freely here. This is why they lie naked on blankets, in empty spots, waiting for each other here.

"Brothers" are what the protagonist's partner calls other homosexual males, and the scrub is primarily an excellent cruising place because it protects the men from the gaze of passers-by. Again, this possibility of freedom comes out of Amager Falled's specific environment-it is simply a result of the place's vegetation, which-in the wording of Lea Løppenthin's poem-is a pattern that wants to use us. The protagonist is placed in the scrubs with his behind bared, and several men pay him a visit at the part- 
ner's instigation. Indeed, the vegetation itself serves as the point of departure of a Jean Genet-like string of images, ${ }^{22}$ beginning as the protagonist sets his eye on a certain branch, while at the same time a number of different actors penetrate him:

Jeg kan ane et træ bag ved busken. En af dets største grene er knækket af, ligger et sted hvor jeg ikke kan se den. Men nu dette: Træets åbne sår, hvorfra det sveder en tyk harpiks. Den flyder brun ned ad stammen, køber ud langs andre grene. Drypper ned i busken foran mig. Jeg ser harpiksen sive langsomt ned langs buskenes stilke, ned ad grene, sive ned i jorden og mærker hænder på mine balder. Mærker, hvordan de skiller dem ad, skaber frit udsyn til min endetarmsåbning. Jeg bliver eksamineret. Spytklatten, der spyttes, tungen, der borer sig ind i min endetarmsåbning, forstår jeg som en godkendelse. (Falk Jensby 2016, 44)

I glimpse a tree behind the bush. One of its largest branches has broken off, and lies in a place where I can't see it. But now this: The tree's open sore from which it is sweating a thick resin. It is floating brown down the trunk, running along other branches. Dripping into the bush in front of me. I am watching the resin slowly sieving along the stalks of the bushes, down branches, sieving into the ground, and sense hands on my buttocks. Feel how they are parted, creating a free view of my anal orifice. I am examined. The gob of spittle being spit out, the tongue drilling its way into my anal orifice, this I understand as approval.

The string of images unites the thick resin with the human spit that is introduced into the anus-resin and spit united by the brown color, as anal sex often leads to the secretion of feces-colored liquids, and since many men come inside the I we are getting quite a wet affair on our hands:

Jeg kan ingenting lige nu. Bare mærke lage løbe overalt: Jeg kan ikke undgå følelsen af,

at jeg skal ligge her i den gennemsigtige harpiks [sæden] resten af mine dage. (Falk Jensby 2016, 48)

Right now I can do nothing. Just feel brine running everywhere: I cannot avoid the feeling that I will lie here, in the see-through resin [the semen], for the rest of my days.

That, though, is not going to be the case. It is time to go home-and the resin-dripping branch has to be carried along: 
Det grønne blad, indhyllet i harpiks. Jeg siger til dig, at vi kan knække den gren af busken, tage den med hjem. At vi kan erstatte orkidéen med den. Du siger okay. Vi kan tage i centret på vej hjem og købe en vase til den. Du går hen til grenen. Dine stærke hænder, albueleddet. Du knækker grenen af, giver den til mig. Harpiksen smitter af på min hånd, får grenen til at klistre sig fast. Vi går ud af det lille buskads. (Falk Jensby 2016, 48)

The green leaf, covered in resin. I am telling you that we can break that branch off the bush, bring it home. That we can use it to replace the orchid. You say okay. We can go to the mall on our way home, and buy a vase for it. You go over to the branch. Your strong hands, the elbow joint. You break off the branch, you hand it to me. The resin stains my hands, makes the branch stick. We leave the small thicket.

The almost over-symbolical branch is therefore placed in the living room, and the I consults his phone, finding an index of "all plants at Amager Falled" ("samtlige planter på Amager Fælled") (Falk Jensby 2016, 49).

The branch is discovered to be of giant knotweed, whose Latin name is Fallopia sachalinensis. The name fallopia connotes- to the I and his partner-phallus ${ }^{23}$ which is clearly understandable given the circumstances. Looking into the plant index reveals that fallopia is the plant family whose Danish name is Silver rain (Fallopia), whose species have arrow- or spearformed leaves. It is hardly necessary to mention what the common connotations of arrows and spears are, the gliding of the signifier being as easy to grasp as a gliding can be.

The point of this entire passage is of course, once more, that it is the specific space of Amager Falled that makes the encounter of bodies possible-or perhaps even furthers it-unsanctioned by the reign of private property, or any other regulatory mechanisms for that matter. The string of images giant knotweed-resin-spear-sweat-semen simply underlines the impact of the environment upon the body that participates in it. This is made quite explicit: "the resin stains my hand, makes the branch stick to it" ("harpiksen smitter af på min hånd, får grenen til at klistre sig fast”) (Falk Jensby 2016, 48).

In the novel the episode on Amager Falled is an unequivocally positive experience in the mind of the I narrator. There is no coercion at all involved in what is happening - no one is taking anything they are not supposed to take. The gangbang in the cruising thicket of Amager Falled is a $100 \%$ ethical act. The I is not even taking drugs, though he often does. 
The ethical aspect of the episode on Amager Falled is, very importantly, highlighted by the contrast it offers to another event in TECHNO. An event that proves completely destructive to the I, since it involves the worst kind of coercion, namely rape. The I is raped by a guy that he has brought home (his partner is in Berlin), and who almost tries to strangle him, triggering a powerful anxiety that will demand treatment and on top of it all ruin the relationship with his boyfriend.

But in the scrubs of the commons there is no coercion-there may even be some kind of community, an experience that the novel, although in a very different manner, shares with Asta Olivia Nordenhof's and Lea Løppenthin's texts on Amager Falled. In Nordenhof, a feeling of belonging with the surroundings is established, a concord that simply needs to be shared, not only with those present, but also with those absent ("must write to morten! must write to bjørn!," "må skrive til morten! må skrive til bjørn!"). In Løppenthin the position of enunciation is collective, cf. "we" ("vi") and "the Tetris formation" ("Tetris-formationen"). And the group perspective is significant in Liv Sejrbo Lidegaard as well, whose debut in 2015 was a volume of poetry that quite simply carried the title Falleden.

\section{Liv Sejrbo LidegaArd: The Common as Common Ground}

The first suite of poems of the volume is called "Close up/close by" ( "Tret på”), and in the suite's second part we once again find ourselves on or around Amager Falled. The first passage goes thus:

har ikke været alene i flere uger. ikke siden en morgen jeg vågnede op på en bænk og frøs, gik hen til et bål, der var en der gav mig en jakke og en cola. har samlet nogle blå kornblomster. vi gik og ledte efter brænde ved stranden. sover let, det er lyst hele tiden. (Lidegaard 2015, 15)

haven't been alone for weeks. not since a morning when i woke/up on a bench freezing, went to a campfire, somebody gave me a/jacket and a coke. have gathered some blue cornflowers. we walked around looking/for firewood on the beach. sleeping lightly, it's bright all the time. ${ }^{24}$

The tone of voice is at one and the same time matter-of-factish and slightly un- or de-realizing. The I has been alone, but is now together with somebody who has fed her (coke) and warmed her (a jacket). It is midsummer 
in Scandinavia (bright all the time, cornflowers), something which may enhance the slightly euphoric state in which the I finds herself. In the first passage we might just be anywhere during the Nordic summer-but the next passage makes it clear that we are likely to be in Amager-on the commons from which the book borrows its name:

flyene er lige over os, flyver tæt på som fuglene. teltet lugter af døde myrer og sidste års græs. vi har hængt vasketøj til tørre i krattet. da jeg vågnede lå mine venner omkring mig og sov. (Lidegaard 2015, 15)

the planes are right above us, flying close by like birds. the tent smells of/dead ants and last year's grass we have hung laundry out to dry in/the thicket. as i woke up, my friends lay sleeping around me.

So the I has gone camping of sorts with her friends, and it is true that planes fly very low over the commons, since the airport is only a few kilometers away. But the question is what valorization is given to this air traffic. The planes are "close by as the birds" ("tæt på som fuglene"), but the equation of "the planes" ("flyene") with "birds" ("fuglene") does not really seem to pose a problem. In the next passage we find the following: "is it orange a sunset or reflecting the lights of the city. the water smells of bog. the planes drown our voices. we cannot start washing our hands now. the air sticks to my skin" ("er det orange en solnedgang eller byens genskær. vandet lugter af mose. flyene overdøver os. vi kan ikke begynde at vaske hænder nu. luften klæber til min hud"). There is a lot to notice here. First, the text works using paratactical, de-hierarchized syntax. All statements are juxtaposed, the text employs lower-case letters. Second, the sunset or the reflection of the city lights, like the planes and birds, is a phenomenon that is described in terms of continuity. One cannot tell what is "natural" and what is "unnatural"-nor is there any point in telling them apart, since "we cannot start washing our hands now"-nothing is pure ("the water smells of bog" and the air "sticks" to the skin). Nothing is pure and the idea that something is able to or would have to be pure is not one with which this kind of environmentally conscious poetry is working. To the pure all things are pure-but here we are rather, like in Nordenhof, getting dirtier. Not being able to wash one's hands is of course both a real experience (there is no clean water nearby) and a stock phrase about not wanting to accept one's guilt, like Pontius Pilate. In this 
case guilt has to do with global warming. Longing for the pre-industrial world is not an option in this text, a point that does not imply that it merely accepts the critical state of the planet. It also speaks of what it is that the group on the commons are "rehearsing" ("øver sig på"), namely "survival" ("overlevelse"). It is as if the camping group were preppers at heart, a position, it has to be said, of abandon.

However, a dynamics evolves within the group, something that barely resembles unmixed, isolationist (deep ecology) resignation. This becomes especially clear from the suite's final passage:

driver langt ned ad stranden. svømmer og vader tilbage mod strømme. løber så hurtigt vi kan. ikke fordi vi har travlt. ikke fordi vi vil komme først. det er ikke en dans. det er et løb. det er ikke et håb, det er et forsøg. rundt om hinanden. salt, sand, maver, vand, tang, alger, småsten, skaller, øjenbryn, eller hjemve, eller vinden som havet for et øjeblik siden. (Lidegaard 2015, 20)

drifting long down the beach. swimming and wading back against the stream. running as fast as we can. not because we are in a hurry. not because we want to be first, it's not a dance, it's a run. it's not a hope, it's an attempt, around each other. salt, sand, bellies, water, seaweed, pebbles shells, eyebrows, or homesickness, or the wind like the sea a moment ago.

These lines are quite an accurate description, not of the pattern of movement of an individual, but of that of a group-a pattern of movement which earlier on, speaking of Løppenthin's poem, I described as a Deleuzian Caucus-race: a perfect example of nomadic distribution. It is NOT a dance (a dance has rules), there are no winners and no losers ("not because we want to be first," "ikke fordi vi vil komme først"), nor is it a teleological movement (there is no "hope" [ "håb"])—but it is an attempt in which the group of bodies even blends together with the rest of the place's physical environment, like small particles of sand that stick to a humid body.

In the already quoted interview from Information, Lidegaard has other interesting proposals about the significance of the Common. The interview was not in fact conducted because of the book of poetry, but because Amager Falled, as I write this, is threatened by invasion: part of the area is simply to be laid out for housing purposes. Besides pointing to the Common's importance as a place to stay "because it has no economical 
value," this is what Lidegaard answers when asked by the journalist about the threatened biodiversity of the site. "There is quite a special fly called the Xanthogramma festivum out here, isn't there?" asks the journalist, and Lidegaard answers:

Yes. And this is a difficult argument to make. A small fly, why would it be important that it doesn't disappear? In a way it doesn't matter, on the other hand it absolutely does matter. And this is partly what has driven me to writing this book. The need for some answers to this question. We are used to thinking about what has value, a kind of utilitarian thought that might be difficult to argue against, just as it is difficult to argue for a space that doesn't have any use. But I have experience of watching places being destroyed she says and refers among other things to the part of Ørestaden that has already been built. (Villesen 2016)

According to Lidegaard, Amager Falled represents an area without utility. A place that does not matter, seen from the viewpoint of the capital, though this does not mean that the capital would not like to make it valid and useful by granting it capital value. It is, however, a place that really does matter seen from the perspective of contemporary Danish literature.

The conclusion must be admissible that the four authors I have mentioned here make a tremendous investment, both in a quite literal, palpable manner and symbolically, in a place known as Amager Folled. And we may now perhaps answer the question why it is that this particular place, this space of given reference, provides the stuff of dreams for other communities and other ways of being in the world than the one offered to us by late capitalist society.

\section{Amager Falled as Political Utopia}

As it has been stressed, Amager Felled is almost in Copenhagen-it is a relatively easy matter for many of the city center inhabitants to go there. At the same time, the very name the commons has a distinct set of connotations both in a Danish and in an international context, nor is Amager Falled the only "common" in Copenhagen. The most well known, and the one that is of greatest relevance to us here, is the area known as Falledparken or the "Commons Gardens"- but which is in fact the old Nørre Folled or "Northern Common." A green area which is probably best known for housing the International Workers' Day, as well as for being adjacent to 
the city stadium, formerly known as Idratsparken, by know reduced to the commercial-colloquial Parken. Nørre Falled was the scene of one of the most important events in Danish political history: "The Battle of the Common" (Slaget på Falleden), which took place on May 5, 1872-only a year after the defeat of the Paris Commune. The Danish workers' leader Louis Pio had called for a grand rally with a view to igniting a revolution, ${ }^{25}$ but was arrested the day before the meeting, and Copenhagen's director of police banned the rally. Notwithstanding, thousands of workers gathered on Nørre Falled, where fighting erupted between workers, police, and hussars who charged the workers with drawn sabers. No one was killed, but many were wounded, and the Battle of the Common must be characterized as the single most violent event in the history of Danish workers. This story bears no relation to the literature of which I am writing here-and then again it does. It is impossible to speak of "the commons" in a Danish context without connoting in one way or another the Battle of 1872, or at least the workers' movement. And while Nørre Falled was a battlefield in the past, Amager Falled may become one in the future. On Sunday, September 16, 2016, more than 2000 people demonstrated against the plans to build high-rises of approximately $260,000 \mathrm{~m}^{2}$ on the most biologically vulnerable part of Amager Falled. The protest took the shape of people taking each other's hands and forming a protective human chain around the salt meadow. It was a quiet protest, and no revolutionary leaflets were circulated, but it is a form of protest that does seem to be able to gather rather a large number of people, to which it must be added that it is in some cases the last remaining resort. On that Sunday on Amager, a future injustice was symbolically "prevented from happening." But this form of protest has been used in other cases, in which the need for protection has been otherwise acute. ${ }^{26}$ So a new battle of the commons may be under way. And contemporary Danish literature contributes to the articulation of what we might perhaps term the place's virtual resources-those returning qualities in places that are brought forth in the writing of texts, and which the geocritical-Deleuzian perspective helps uncover. They are first and foremost:

- An experience of community and solidarity-not just between humans but with the surroundings as such.

- The experience of an open (nomadic) space in which the movements of the body are not regulated in advance, and wherein the human relationship with the surroundings is marked by continuity. 
- A space where biodiversity is able to thrive without being enclosed. The Commons is not a reservation.

- A site free from coercion, where there is room for exchange that cannot be capitalized.

This is quite a lot at one and the same time, but it is striking how interconnected the questions and the thematics of these texts are. Amager and Amager Felled as late capitalist utopia-machines?

The last chapter in the history of Shitty Island most definitely remains to be written.

\section{Notes}

1. All translations are mine unless other translators are mentioned.

2. This text does not intend to provide a comprehensive literary history of Amager as a motif. Although this would in fact be a welcome thing, my emphasis will still be on contemporary literature. Two other depictions of Amager in Danish literature that are both extremely interesting and rather ambiguous should, however, not go unmentioned: Hans Christian Andersen's (2004) Fodreise fra Holmens Canal til Østpynten af Amager $i$ aarene 1828 og 1829, and Klaus Rifbjerg's Amagerdigte (1965).

3. Vidensindsamling Natur 2013 Amager Falled, Biomedia, Rapport til Københavns Kommune. Written by Anders N. Michaelsen and Johanne Bak, Biomedia and Lars Andersen. Handed in for publication.

4. Blót is the Old Norse name for sacrifice.

5. In Denmark, the corresponding reorganization of agriculture is known as udskiftningen and takes place around 1800; it has its own local history.

6. See, for instance, Capital, I, chapter 27. My account, however, primarily follows Silvia Federici's analysis of the enclosure's significance as presented in Federici's (2004) book Caliban and the Witch: Women, the Body, and Primitive Accumulation.

7. For examples of the World Bank driving people away from areas of common exploitation, see, for instance, Silvia Federici and George Caffentzis: "Commons Against and Beyond Capitalism" (2013).

8. As is well known, Timothy Morton (2007) has suggested that we stop speaking of "nature" and start speaking of "the environment" instead. In short, nature is automatically framed as an "outside," whereas we are inextricably entangled with our environment, the latter notion being of course a basic assumption of ecology.

9. It is the book that has attracted the greatest amount of comment. In the newspaper Information, May 5, 2014, the author of these lines described 
it as eco-critical in the article "Litteratur der gør den økologiske bevidsthed sanselig"; Jens Kramshøj Flinker analyses it in terms of an ideological critique of neoliberal developments in society, whereas Tue Andersen Nexø (2016) has an almost opposite interpretation of it as a rebuttal of the welfare state. See Jens Kramshøj Flinker (2013): Litteratur i 00'erne-en ny ideologikritik and Tue Andersen Nexø: Vidnesbyrd fra velferdsstaten.

10. Translated by Susanna Nied to whom I wish to express my warmest thanks.

11. "Lovgivning vedrørende Ørestad" ("Legislation concerning Ørestad") was voted in 1992. The "unused" areas of Amager were considered far too valuable for them just to be left to lie, and on March 11, 1993, Ørestadsselskabet (The Ørestad Company) was founded, its mission being to manage the growth of the newly founded district.

12. The construction of the metro has been marred by numerous "scandals": social dumping, corruption, messy accounts and lack of tax payments, illegal firings, and so on. This is, according to the Danish social scientist Bent Flyvbjerg, inevitably the case in large public construction projects, but as he says in an interview with DJØF-bladet (January 19, 2014) an untamable desire for recognition and profit prevents the initiators from drawing a lesson from the sins of the past: "Politicians adore mega-projects like monuments. They provide media attention, both when they are started, and when there is a ribbon to cut. At the same time, the huge financial scope of these projects means that there is a lot of money to be made by a lot of actors. Consulting firms, construction firms, lawyers, labor and management, and finally engineers, who love the projects because they are innovative and groundbreaking and may become drivers of the development of technological know-how that can be sold abroad."

13. Morton's ecology is above all dark because it includes the ugly or unbeautiful—not just butterflies and oaks but fried chicken and beer cans are also part of the environmental circuit.

14. Translation by Peter Borum and myself. My thanks to Lea Løppenthin for providing a very helpful draft.

15. In Poetics of Relation $(2000,59)$ Édouard Glissant (becoming thereby complementary to Deleuze and Guattari) distinguishes "arrowlike" territorialization-for instance that of colonization-from "wandering," "circling" territorialization-for instance that for which the wandering poet stands. This corresponds fairly well to what Westphal says about territorialization in La Géocritique (2007, 87-96), since he also has need of a nonconquering concept of territorialization.

16. Rosi Braidotti strongly stresses that "nomadic subjectivity" has nothing to do with being a refugee or having no fixed residence. See Rosi Braidotti: "By Way of Nomadism" in Nomadic Subjects: Embodiment and Sexual Difference in Contemporary Feminist Theory, 1994. 
17. It is telling that the need for biopolitical control of reproduction, which in Federici's compelling analysis forms the basis of the witch trials, fosters ideas of nocturnal sex orgies in unenclosed spaces (Federici 2004, 192-8).

18. See http://www.religion.dk/andre-religioner-og-trosretninger/hvadbygger-asatroende-deres-religions-paa-i-sag.

19. In Homoseksuel Sex-Guide København one finds the following description in a review of Amager Falled: "Location: Large Natural Reserve in Amager." There are two good places: http://findvej.dk/55.65406,12.56 98 : zoom $=16 \&$ maptype $=3$ and $\ldots$ http: $/ /$ findvej.dk $/ 55.65013,12.5687$ ? zoom=16\&maptype $=3$. "Time: on principle all day from 9 AM until 10 PM. Activity: moderate to high ... mostly in summer. Who goes there: mostly between 25 and 75 years old. ... MY ASSESSMENT FROM 1-6 STARS: $* * * *$ (super nice natural surroundings with lots of space-but too many exhibitionist nudists and sometimes too little action)." http://sol. $\mathrm{dk} /$ debat/homoseksuel-sex-guide-k\%C3\%B8benhavn.

20. When Ursula Andkjær Olsen and I edited the first issue of the journal Kritik in the spring of 2013 , the theme was "gentrification." We had a hard time finding Danish contributors, and the notion itself was subjected to a devastating critique from the literary editor of Denmark's largest cultural newspaper Politiken, the very idea of problematizing "gentrification" being regarded as viewing matters from an elitist perspective. Much has changed since then, but it is obviously difficult for the Scandinavian welfare model to accept the questioning of prevalent models of urban planning.

21. All translations from TECHNO are by Peter Borum and myself. They have been approved by Niels Henning Falk Jensby.

22. See the famous vaseline passage from the Journal du voleur (1982)—brilliantly analyzed by Derrida in Glas, 1974.

23. In fact, it refers to the Italian sixteenth-century scientist Gabriele Falloppio, so from this perspective there is no reference to the erect penis. Then again, Falloppio is known, among other things, for being the first to describe a condom in scientific terms.

24. All translations by Liv Sejrbo Lidegaard.

25. In the pamphlet calling for the rally, entitled "Maalet er fuldt" (Pio 2016; "Our cup is full"), it says, among other things: "Should we allow ourselves to be led like lambs to the slaughter by Capital? Should we suffer that our enemies stop our advance, perhaps for years on end? No, the workers of Copenhagen cannot in all decency let this pass! Let us therefore gather together; governments are anytime prone to hold a review of those of their subjects whom they sacrifice on the altar of war-madness at the first given occasion in order to satisfy their ambition. So let us then muster all free workers, all who will help us in the struggle against capital; then we shall 
know our own power and the weakness of our enemies; gathered in the thousands we will state our claims and promise each other to stand shoulder by shoulder until victory is ours! But you, worshippers of gold! You, blood-suckers of the poor! You shall be met once again with the clamor: 'For millenia you have been pouring us a bitter drink of life; beware, our cup is full! Let not a single drop fall into it or-it overflows!"” https:// www.arbejdermuseet.dk/wp-content/uploads/2016/10/2402140_ kilde-1-2.pdf.

26. http://politiken.dk/debat/ECE247561l/behoever-lykke-at-vaere-synonymt-med-selvtilstraekkelighed-for-danskerne/. This article by Danish writer Carsten Jensen (2014) describes an attempt to save two Afghan children from being deported by forming a protective circle of human bodies around them at Copenhagen Airport.

\section{REFERENCES}

Andersen, Hans Christian. 2004. Fodreise fra Holmens Canal til Østpynten af Amager $i$ aarene 1828 og 1829. København: Det Danske Sprog- og Litteraturselskab.

Braidotti, Rosi. 1994. By Way of Nomadism. In Nomadic Subjects: Embodiment and Sexual Difference in Contemporary Feminist Theory, 1-41. New York: Columbia University Press.

Culler, Jonathan. 1981. Apostrophe. In The Pursuit of Signs: Semiotics, Literature, Deconstruction, 135-155. Ithaca: Cornell University Press.

Deleuze, Gilles. 2004 [1969]. The Logic of Sense. Translated by Mark Lester with Charles Stivale, edited by Constantin V. Boundas. London: Continuum Impacts.

Deleuze, Gilles, and Félix Guattari. 1980. Capitalisme et schizophrénie 2: Mille plateaux. Paris: Les Éditions de Minuit.

Derrida, Jacques. 1974. Glas. Paris: Editions Galilée.

Falk Jensby, Niels Henning. 2016. TECHNO. København: Gyldendal.

Federici, Silvia. 2004. Caliban and the Witch: Women, the Body, and Primitive Accumulation. New York: Autonomedia.

Federici, Silvia, and George Caffentzis. 2013. Commons Against and Beyond Capitalism. Upping the Anti: A Journal of Theory and Action 15 (September): 83-97.

Flinker, Jens Kramshøj. 2013. Litteratur i 00'erne-en ny ideologikritik. Hellerup: Spring.

Genet, Jean. 1982 [1949]. Journal du voleur. Paris: Gallimard.

Glissant, Édouard. 2000 [1990]. Poetics of Relation. Translated by Betsy Wing. Ann Arbor: University of Michigan Press.

Heiberg, Johanne Louise. 1944 [1891]. Et liv gjenoplevet i Erindringen 1842-49, vol. II. København: Arkiv for dansk litteratur. 
Jensen, Carsten. 2014. Behøver lykke at være synonymt med selvtilstrækkelighed for danskerne? Politiken, December 7.

Lidegaard, Liv Sejrbo. 2015. Falleden. København: Gyldendal.

Lindegaard, Hanne. 2001. Ud af roret? Planer, processer og paradokser omkring det Københavnske kloaksystem 1840-2001. PhD thesis, DTU.

Løppenthin, Lea Marie. 2014. nervernes adresse. København: Gladiator.

Marx, Karl. 1867. Das Kapital, I. Otto Meissner: Hamburg.

Michaelsen, A.N. et al. 2014. Vidensindsamling Natur 2013 Amager Falled. Biomedia foril Københavns Kommune. January. http://www.avlu.dk/wp-content/2014/09/Vidensindsamling-Natur-Amager-Fælled-2013.pdf.

Morton, Timothy. 2007. Ecology without Nature: Rethinking Environmental Aesthetics. Cambridge, MA and London: Harvard University Press.

Nexø, Tue Andersen. 2016. Vidnesbyrd fra velferdsstaten. København: Arena.

Nordenhof, Asta Olivia. 2013. det nemme og det ensomme. København: Forlaget Basilisk.

Olsen, Ursula Andkjær, and Elisabeth Friis. 2013. Kritik, “Gentrificering," no. 207. København: Gyldendal.

Pape, Morten. 2015. Planen. København: Gyldendal.

Pio, Louis. 2016 [1872]. Maalet er fuldt. https://www.arbejdermuseet.dk/wpcontent/uploads/2016/10/2402140_kilde-1-2.pdf.

Rifbjerg, Klaus. 1965. Amagerdigte. København: Gyldendal.

Schulman, Sarah. 2013. The Gentrification of the Mind: Witness to a Lost Imagination. Berkeley, Los Angeles, London: University of California Press.

Westphal, Bertrand. 2007. La Géocritique: Réel, Fiction, Espace. Paris: Les Éditions de Minuit.

\section{Other Resources}

“Lovgivning vedrørende Ørestad" ("Legislation concerning Ørestad"). 1992. https://www.retsinformation.dk/eli/ft/199112K00024.

DJØF-bladet. 2014, January 19. http://www.djoefbladet.dk/blad.aspx?y=2014.

Villesen, Kristian. 2016. Slaget om Fælleden. Information, October 8. https://www. information.dk/mofo/farvel-sidste-sted-omkring-formaaet-lade-vaere-fred. 
Open Access This chapter is licensed under the terms of the Creative Commons Attribution 4.0 International License (http://creativecommons.org/licenses/ by $/ 4.0 /)$, which permits use, sharing, adaptation, distribution and reproduction in any medium or format, as long as you give appropriate credit to the original author(s) and the source, provide a link to the Creative Commons licence and indicate if changes were made.

The images or other third party material in this chapter are included in the chapter's Creative Commons licence, unless indicated otherwise in a credit line to the material. If material is not included in the chapter's Creative Commons licence and your intended use is not permitted by statutory regulation or exceeds the permitted use, you will need to obtain permission directly from the copyright holder.

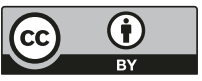

